\title{
Water scarcity and contamination in eastern Ukraine
}

\section{Y. VYSTAVNA \& D. DIADIN}

\section{O.M. Beketov National University of Urban Economy at Kharkiv, Ukraine} vystavna@yahoo.com

Water resources have uneven distribution throughout the territory of Ukraine. The economic planning during the Soviet period was based mostly on the transport logistics and centralization, and resulted in the location of most industrial and urbanized areas in water-scarce regions of eastern Ukraine. Longterm anthropogenic pressure on the limited water resources of this part of Ukraine have caused the growth of water crises and high costs for ensuring water security. At present, the transboundary (Russia/Ukraine) Seversky Donets water basin $\left(98900 \mathrm{~km}^{2}\right)$ is considered as the main water supply to three big industrial and highly urbanized regions of Ukraine: Kharkiv, Donetsk and Lugansk, and plays an important socio-economic role as a major source of industrial and drinking water to about 5 million inhabitants. Since 2008, our research team has been conducting long-term investigative monitoring of surface and groundwaters in the Seversky Donets at 40 sites (Fig. 1) in the transboundary, rural and urban areas, including the survey of surface waters in four rivers of the basin, groundwaters (springs and wells) and precipitation.

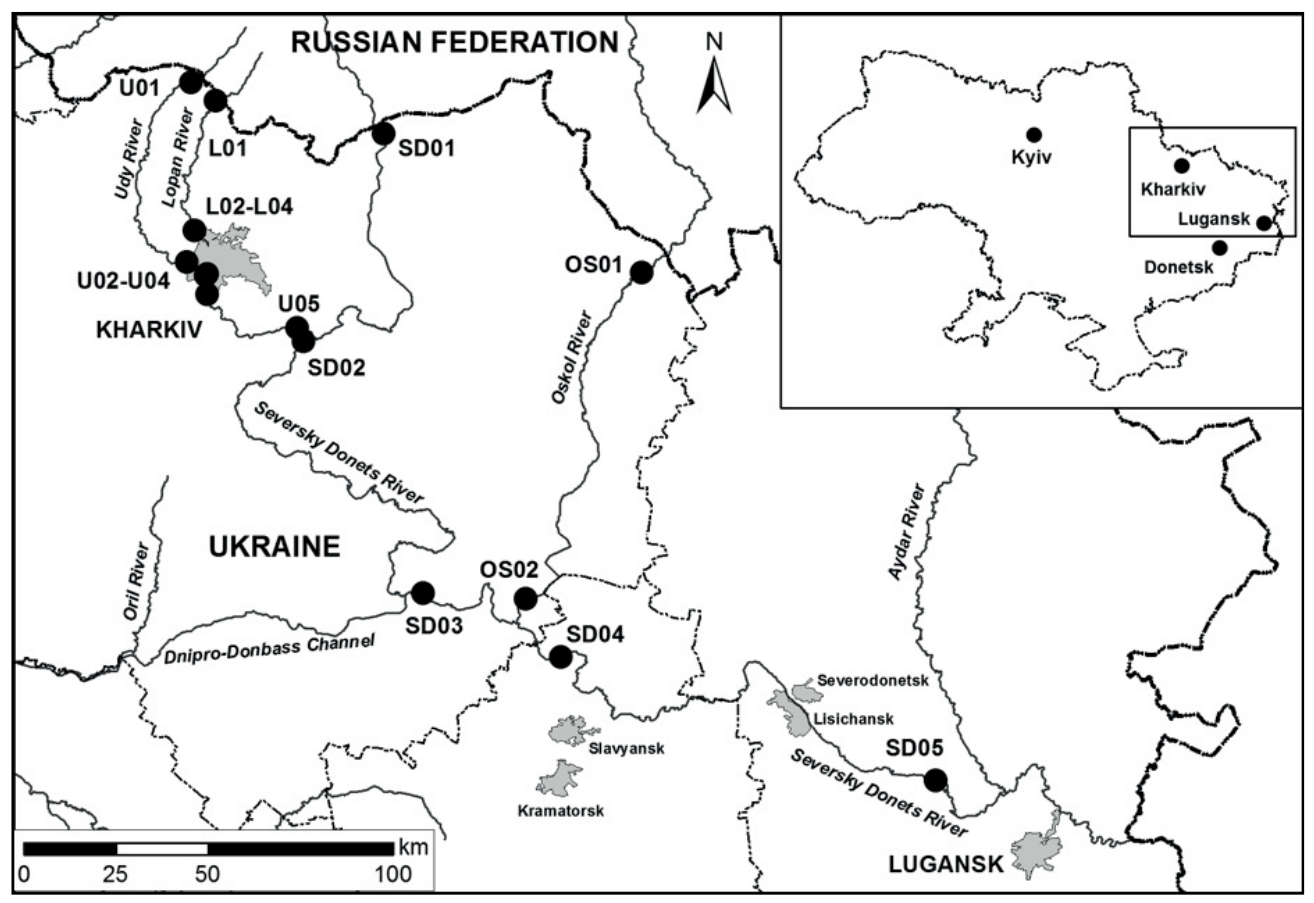

Fig. 1 The location of the Seversky Donets watershed and sampling sites.

The aim of our research is to study hydrological and hydrochemical changes in the watershed and assess the environmental and health hazards/risks associated with the different water uses, including drinking supply. The analysis comprises the following parameters: water flow, temperature, conductivity, $\mathrm{pH}$, redox, major ions, environmental isotopes, nutrients, emerging contaminants (endocrine disruptors, pharmaceuticals and nanomaterials) and trace metals. The results of the research were: (i) identification of natural and anthropogenic determinants that influence water quality and quantity; (ii) the environmental and health impact assessment of the water use and drinking supply; and (iii) modelling of the water quality dependence on the socio-economic dynamics. 
Among the natural factors (Vystavna et al. 2012a,b,c) influencing the hydrology and water chemistry are the precipitation balance, interaction of water with geological formations (mainly Cretaceous carbonate rocks and loams) and evaporation. Meteorological observations revealed the continentally increasing climate, where the extremely high temperature (up to $40^{\circ} \mathrm{C}$ ) and dryness in May-September stimulate the evaporation process and decrease the water availability. Evaporation, together with the additional anthropogenic inputs, was the reason for the growth of the salinity of groundwater, especially in urban areas where the salt content increased up to $2 \mathrm{~g} \mathrm{~L}^{-1}$.

Anthropogenic factors such as water flow regulation, weakly controlled water extraction, discharge of insufficiently treated and contaminated wastewaters and runoff to the water bodies are responsible for the water quality changes and pollution events (Vystavna et al. 2012a,b,c). Most pollutants enter natural water as uncontrolled inputs and are difficult to identify and monitor. High water contamination by trace metals and pharmaceuticals (e.g. carbamazepine concentration was up to $1 \mu \mathrm{g} \mathrm{L}^{-1}$ in riverine water downstream of Kharkiv city; Vystavna et al. 2013) were found in urban areas. Nutrient pollution (nitrates) was detected in groundwater in the territory of smaller settlements, where the population use groundwater for household needs and drinking supply. Currently, surface and groundwater quality in the Seversky Donets basin does not comply with the Ukrainian water limits for drinking water supply. The EU limits were exceeded for some of alkylphenols (more than 7 times), $\mathrm{Cd}, \mathrm{Pb}$ and nutrients.

The water monitoring of the main water basin in eastern Ukraine revealed that the threats to water security are associated with: (i) climate changes that are responsible for the intensification of evaporation processes and decrease of water availability; (ii) high level of water contamination by trace metals and emerging pollutants, which are weakly controlled by Ukrainian legislation; and (iii) allocation of water resources and the growth of the competition between users.

All these problems lead to the decrease of living standards, the growth of the water-related disease and economic losses.

Acknowledgement Our study is partly funded via the CRP 33020 cooperative research project of the International Atomic Energy Agency.

\section{REFERENCES}

Vystavna, Y. et al. (2012a). Monitoring and flux determination of trace metals in rivers of the Seversky Donets basin (Ukraine) using DGT passive samplers. Environ. Earth Sci. 65, 1715-1725.

Vystavna, Y. et al. (2012b). Distribution of trace elements in waters and sediments of the Seversky Donets transboundary watershed (Kharkiv region, Eastern Ukraine). Appl. Geochem. 27(10), 2077-2087.

Vystavna, Y. et al. (2012c). Pharmaceuticals in rivers of two regions with contrasted socio-economic conditions: occurrence, accumulation and comparison for Ukraine and France. Water Air Soil Poll. 223(5), 2111-2124.

Vystavna, Y., Le Coustumer, P. and Huneau, F. (2013) Monitoring of trace metals and pharmaceuticals as anthropogenic and socioeconomic indicators of urban and industrial impact on surface waters. Environ. Monit. Assess. 185(4), 3581-3601. 